Zbigniew Bereszyński

(Instytut Śląski)

dr, zbereszynski@wp.pl

ORDCID iD: 0000-0001-9761-8701

\title{
Strategia dynamicznego rozwoju i jej realizacja na przykładzie Opola w latach 1971-1980
}

W 1971 r. nowe kierownictwo Polskiej Zjednoczonej Partii Robotniczej, na czele z Edwardem Gierkiem jako I sekretarzem Komitetu Centralnego PZPR, wdrożyło nową strategię gospodarczą, określaną jako strategia dynamicznego rozwoju. Strategia ta przewidywała w szczególności szybki rozwój potencjału przemysłowego kraju w połączeniu z wyraźną poprawą materialnych warunków życia społeczeństwa. Na obradującym w dniach 6-11 grudnia 1971 r. VI Zjeździe PZPR oficjalnie przyjęto program „dynamicznego rozwoju" i „dalszego budownictwa socjalizmu w Polsce"1.

W realizację tego programu aktywnie włączyły się również władze polityczne i administracyjne województwa opolskiego. W latach 1971-1972 wystarały się one o znaczne zwiększenie nakładów finansowych na przyspieszony rozwój gospodarczy regionu. Zgodnie z ustaleniami poczynionymi w czerwcu 1972 r., nakłady na inwestycje przemysłowe w województwie opolskim miały wynieść łącznie ponad $23 \mathrm{mld}$ zl, co oznaczało wzrost o 118 proc. w stosunku do poprzedniej pięciolatki (analogiczny wzrost w latach 1966-1970 wyniósł 9,5 proc.) $)^{2}$.

${ }^{1}$ A.L. Sowa, Historia polityczna Polski 1944-1991, Kraków 2011, s. 384; P. Sasanka, Czerwiec 1976. Geneza - przebieg - konsekwencje, Warszawa 2017, s. 33.

${ }^{2}$ Archiwum Państwowe w Opolu (dalej: APO), Komitet Wojewódzki Polskiej Zjednoczonej Partii Robotniczej (dalej: KW PZPR) w Opolu, 106, Sprawozdanie z realizacji zaleceń Sekretariatu KC PZPR w sprawie inicjatyw Opolskiej Organizacji Partyjnej w dziedzinie przyspieszenia i usprawnienia procesów gospodarczych, społecznych i politycznych województwa, 28 grudnia 1972 r.; tamże, Postęp techniczny i usprawnienie gospodarki materiałowej w przemyśle województwa opolskiego (materiał na Plenum KW PZPR), marzec 1973 r.; APO, KW PZPR w Opolu, 107, Postęp techniczny i usprawnienie gospodarki materiałowej w przemyśle województwa opolskiego (materiał na Plenum KW PZPR), marzec 1973 r. Zob. Z. Bereszyński, Pod 
Szczególnie ważne miejsce w planach dynamicznego rozwoju społeczno-gospodarczego regionu zajmowała od początku stolica województwa. Działania podejmowane począwszy od 1971 r. zmierzały w sposób dość konsekwentny do znacznego wzmocnienia pozycji zajmowanej przez Opole w życiu społecznym regionu, ze szczególnym uwzględnieniem życia gospodarczego, kultury i nauki.

Kluczowe decyzje w tym zakresie były podejmowane przez ówczesne władze polityczne województwa, reprezentowane przez Komitet Wojewódzki PZPR z jego Egzekutywą i Sekretariatem. W praktyce najwięcej zależało od woli kolejnych osób na stanowisku I sekretarza KW PZPR. W latach 19711980 funkcję tę sprawowali w województwie opolskim kolejno: Józef Kardyś (od lutego 1971 r.), Andrzej Żabiński (od marca 1973 r.) i Józef Masny (od lutego $1980 \mathrm{r}$.) $)^{3}$.

Decyzje ówczesnych decydentów politycznych na szczeblu wojewódzkim w większym lub mniejszym stopniu wpisywały się $\mathrm{w}$ strategię obraną przez centralne kierownictwo partii. W znacznej mierze wypływały jednak również z osobistych i środowiskowych ambicji przedstawicieli lokalnego aparatu władzy. Mechanizm taki przejawił się w sposób szczególnie jaskrawy w okresie, gdy I sekretarzem KW PZPR w Opolu był A. Żabiński.

W przypadku stolicy województwa znacznie mniej do powiedzenia miały władze partyjne szczebla miejskiego i powiatowego. Do czasu likwidacji powiatów w 1975 r. były one reprezentowane przez Komitet MiejskoPowiatowy PZPR w Opolu, a w późniejszym czasie przez Komitet Miejski PZPR. Władze te mogły podejmować decyzje w sprawach mniejszej rangi, nie obejmujących kluczowych przedsięwzięć inwestycyjnych. Ich wpływ na kształtowanie się sytuacji w mieście wzrósł nieco po 1975 r., gdy sprawy miejskie zostały oddzielone od spraw byłego powiatu opolskiego. Nadal jednak był to wpływ niewielki w porównaniu z zakresem władzy i zainteresowań Komitetu Wojewódzkiego PZPR.

Ważną rolę we wdrażaniu nowej strategii gospodarczej odgrywały również miejscowe władze administracyjne, reprezentowane do listopada $1973 \mathrm{r}$. przez prezydia wojewódzkiej i miejskiej rady narodowej, a następnie, po gruntownej reorganizacji struktur administracji państwowej w Polsce, przez wojewodę opolskiego i prezydenta miasta Opola wraz z podległymi im urzędami. Władze te spełniały jednak funkcję służebną w stosunku do władz politycznych. Ich rola polegała w głównej mierze na przygotowywaniu mate-

znakiem "dynamicznego rozwoju”. Strategia gospodarcza PZPR po Grudniu'70 i jej realizacja na przykładzie województwa opolskiego - od optymistycznych prognoz i deklaracji po pierwsze oznaki kryzysu, „Studia Śląskie” 2016, t. 78, s. 80.

${ }^{3}$ M. Sroka, I sekretarze Komitetu Wojewódzkiego Polskiej Zjednoczonej Partii Robotniczej w Opolu w latach 1950-1990, "Studia Śląskie” 2016, t. 78, s. 27-64. 
riałów niezbędnych do podejmowania ważnych strategicznie decyzji przez właściwe władze PZPR i na spełnianiu funkcji wykonawczych w odniesieniu do podejmowanych w takim trybie ustaleń.

U progu dekady 1971-1980 Opole, mimo wysokiej rangi administracyjnopolitycznej, było miastem średniej wielkości, liczącym się jako ważny węzeł komunikacji w sieci dróg kołowych, kolejowych i wodnych, ale pozbawionym wielkiego przemysłu. W 1970 r. obejmowało ono obszar $52 \mathrm{~km}^{2}$, zamieszkiwany przez 86900 osób $^{4}$. Jednym dużym zakładem pracy na terenie miasta były w tym czasie Zakłady Naprawcze Taboru Kolejowego „Opole”, zatrudniające wówczas około 2400 osób, nie licząc 500 uczniów przyzakładowej szkoły zawodowej ${ }^{5}$. Swoistą „wizytówkę" miejscowego przemysłu stanowiły cztery cementownie: „Odra”, „Piast”, „Bolko” i Groszowice”. Zatrudniały one jednak stosunkowo niedużą liczbę osób, a ich działalność była bardzo uciążliwa dla mieszkańców miasta z uwagi na powodowane przez nie zapylenie. Szczególnie negatywny wpływ na sytuację w mieście miała działalność cementowni „Piast” i „Bolko”. Pod względem stopnia uprzemysłowienia Opole pozostawało $\mathrm{w}$ tyle za kilkoma innymi ośrodkami miejskimi w województwie opolskim, a w szczególności za Kędzierzynem i Nysą.

Od 1954 r. działała w Opolu Wyższa Szkoła Pedagogiczna ${ }^{6}$. W roku akademickim 1965/66 powołano Wyższe Zawodowe Studium Techniczne, które z kolei w czerwcu 1966 r. przekształcone zostało w Wyższą Szkołę Inżynierską ${ }^{7}$. Baza materialna tych uczelni, ze szczególnym uwzględnieniem budynków, przedstawiała się jednak dość skromnie. Najubożej pod tym względem przedstawiała się miejscowa WSI, znajdująca się dopiero w stadium zalążkowym. Pracownicy i studenci WSP uskarżali się w szczególności na brak odpowiednich pomieszczeń dla uczelnianej biblioteki. W $1957 \mathrm{r}$. reaktywowano w Opolu działalność Instytutu Śląskiego, placówki naukowej sięgającej swoimi tradycjami jeszcze okresu międzywojennego ${ }^{8}$. Placówka ta zatrudniała liczną kadrę naukową oraz odgrywała ważną rolę w życiu naukowym i społeczno-kulturalnym regionu. Warunki pracy w Instytucie były

${ }^{4}$ APO, Urząd Miejski (dalej: UM) w Opolu, 1801, Kroniki i monografie własne. Kronika miasta Opola 1980, s. 124.

${ }^{5}$ APO, Komitet Zakładowy PZPR przy Zakładach Naprawczych Taboru Kolejowego w Opolu, 3, Zakłady Naprawcze Taboru Kolejowego „Opole” w Opolu - charakterystyka, rozwój i perspektywy, 7 maja 1969 r., bp.

${ }^{6}$ Od 1994 r. Uniwersytet Opolski. Zob. S.S. Nicieja, Alma Mater Opoliensis. Ludzie - fakty wydarzenia. Księga jubileuszowa w 50. rocznice Wyższej Szkoły Pedagogicznej w Opolu i 10. rocznice powstania Uniwersytetu Opolskiego, Opole 2004, s. 17-19, 22-24.

${ }^{7}$ Od 1996 r. Politechnika Opolska. APO, KW PZPR w Opolu, 339, Informacja w sprawie uruchomienia i rozwoju Wyższej Szkoły Inżynierskiej w Opolu, 11 X 1966 r., s. 62.

${ }^{8}$ M. Lis, Historia PIN - Instytutu Ślaskiego w Opolu, Państwowy Instytut Naukowy - Instytut Śląski w Opolu, https:/ /instytutslaski.pl/historia-instytutu-slaskiego/ (dostęp: 28 października 2020 r.). 
jednak bardzo trudne z uwagi na brak odpowiedniej liczby pomieszczeń i panującą w nich ciasnotę.

Wszystko to przemawiało za podjęciem różnego rodzaju przedsięwzięć inwestycyjnych $\mathrm{w}$ celu poprawienia sytuacji $\mathrm{w}$ rozmaitych sferach życia społecznego na terenie Opola. Zmiany zaistniałe w kraju w 1971 r. stworzyły po temu znakomitą okazję.

Do pierwszych ważniejszych przejawów nowego kursu w sprawach dotyczących rozwoju społeczno-gospodarczego Opola można zaliczyć przebieg Wojewódzkiej Konferencji Przedzjazdowej, zwołanej na 6 listopada 1971 r. w ramach przygotowań do VI Zjazdu PZPR ${ }^{9}$. Zgodnie ze złożoną wówczas deklaracją, wojewódzkim władzom PZPR zależało na umocnieniu gospodarczej pozycji Opola jako stolicy regionu i wzmocnieniu miejscowych środowisk robotniczych, postrzeganych jeszcze wtedy - mimo doświadczeń Grudnia '70 jako społeczna ostoja systemu "socjalistycznego". W związku z tym zabiegano o ulokowanie w tym rejonie nowego "zakładu kluczowego, nastawionego na produkcję finalną i zatrudniającego około trzech - czterech tysięcy osób"10. Tak zaczęła się do droga do powstania późniejszych Zakładów Aparatury Chemicznej „Metalchem” w Opolu.

W grudniu 1971 r. Egzekutywa Komitetu Wojewódzkiego PZPR uznała za konieczne zbudowanie nowej siedziby Instytutu Śląskiego w Opolu. Prezydium Wojewódzkiej Rady Narodowej zostało zobowiązane do „podjęcia energicznych starań $\mathrm{w}$ celu przyspieszenia budowy nowego lokalu" dla tej placówki naukowej, jak również do zapewnienia terminowej realizacji owej inwestycji ${ }^{11}$.

$\mathrm{Na}$ pierwszym noworocznym posiedzeniu Egzekutywy KW PZPR w styczniu 1972 r. zobowiązano „Wydział Ekonomiczny KW do przedstawienia koncepcji budowy w Opolu trzech nowoczesnych zakładów przemysłowych, zapewniających miastu rozwój a mieszkańcom pracę". Sprawami związanymi z rozwojem miasta miało zająć się również Towarzystwo Przyjaciół Opola, zobowiązane do poświęcenia tej tematyce kilku „konferencji naukowych z udziałem wybitnych fachowców, urbanistów, ekonomistów"12.

${ }^{9}$ APO, KW PZPR w Opolu, 100, Uchwała Wojewódzkiej Konferencji Przedzjazdowej PZPR w Opolu (projekt), 6 listopada 1971 r., s. 352.

${ }^{10}$ APO, KW PZPR w Opolu, 31, Referat Egzekutywy KW PZPR na Wojewódzką Konferencję Przedzjazdową w Opolu, listopad 1971 r., s. 549.

${ }^{11}$ APO, KW PZPR w Opolu, 365, Protokół nr 39/71 z posiedzenia Egzekutywy Komitetu Wojewódzkiego PZPR w Opolu, odbytego w dniu 16 grudnia 1981 r., s. 136; tamże, Uchwała Egzekutywy Komitetu Wojewódzkiego PZPR w Opolu w sprawie Instytutu Śląskiego w Opolu Załącznik nr 4 do Protokołu nr 39/71 z posiedzenia Egzekutywy Komitetu Wojewódzkiego PZPR w Opolu, odbytego 16 grudnia 1981 r., s. 184.

${ }^{12}$ APO, KW PZPR w Opolu, 366, Protokół nr 1/72 z posiedzenia Egzekutywy Komitetu Wojewódzkiego PZPR w Opolu, odbytego w dniu 8 stycznia 1972 r., s. 4-5. 
Na tym samym posiedzeniu przewodniczący Prezydium Miejskiej Rady Narodowej w Opolu, Franciszek Florkiewicz, przedstawił koncepcję rozwoju miasta, rozłożonego na trzy etapy. Etap pierwszy miał obejmować „zagospodarowanie dzielnicy Opole-Wschód w sensie rekreacyjno-wypoczynkowym, handlowo-usługowym, budowy sieci żłobków, przedszkoli, szkół". W drugim etapie zamierzano unowocześnić Zaodrze. Przedsięwzięcie to miało jednak wiązać się z częściowym wyburzeniem dotychczasowej zabudowy dzielnicy. Etap trzeci miał nadać nowe oblicze śródmieściu. Także tutaj planowano „pewne przesunięcia ulic”. Miało powstać „wiele nowych obiektów”, jak ośmiopiętrowy hotel, centrum usługowo-handlowe oraz nowe siedziby Instytutu Śląskiego, Muzeum Śląska Opolskiego i Wojewódzkiej Biblioteki Publicznej ${ }^{13}$.

Prognozowano, że w latach 1972-1985 liczba mieszkańców Opola wzrośnie z około 90000 do 130 000, a przy odpowiedniej „intensyfikacji inwestycji produkcyjnych, [rozwoju] ośrodka naukowo-badawczego, usług i co za tym idzie, inwestycji mieszkaniowych", może nawet do 150 000. Przyrost ten miał być w głównej mierze, a mianowicie w 65-70 proc., efektem migracji, a tylko w 30-35 wynikać z przyrostu naturalnego. W 2000 r. Opole miało liczyć już około 200000 mieszkańców ${ }^{14}$. Rozwój przestrzenny miasta miał obejmować w szczególności: ukształtowanie „dzielnicy przemysłowej we wschodniej części miasta” oraz "trzech dzielnic przemysłowo-składowych" we wschodniej, zachodniej i północnej części miasta (odpowiednio rejon od Zakładów Naprawczych Taboru Kolejowego po Gosławice, Półwieś oraz Zakrzów), uformowanie "centralnego ośrodka usługowo-dyspozycyjnego w śródmieściu”, budowę nowoczesnej dzielnicy mieszkaniowej OpoleWschód dla około 40000 mieszkańców, zagospodarowanie wyspy Bolko oraz terenów położonych na brzegami Odry i kanałem Ulgi, „wzbogacenie układu miejskiego o pasy zieleni na obszarze całego miasta dla celów rekreacyjnych i sportowych”, "rozbudowanie na osi ul. Oleskiej zespołu wyższych uczelni z domami studenckimi i urządzeniami towarzyszącymi", a także wytworzenie "prawidłowego układu komunikacyjnego" na zasadzie modernizacji istniejących dróg oraz "budowy nowych arterii miejskich i przelotowych". Po 1975 r. budownictwo mieszkaniowe miało rozwijać się w zachodniej części miasta, a przemysł w części wschodniej i ewentualnie południowej (w rejonie Groszowic). Zamierzenia te oznaczały w szczególności konieczność wybudowania około 20000 izb mieszkalnych w okresie do 1985 r. ${ }^{15} \mathrm{~W}$ ra-

${ }^{13}$ Tamże, s. 3-4.

14 Tamże, Kierunki rozwoju miasta Opola w latach 1972-1990. Załącznik nr 6 do Protokołu nr 1/72 z posiedzenia Egzekutywy KW [PZPR] odbytego 8 stycznia 1972 r., s. 28-29.

15 Tamże, s. 29-32. 
mach przebudowy śródmieścia miał powstać m.in. nowy dworzec autobusowy ${ }^{16}$.

W 1972 r. rozpoczęto budowę pierwszego z trzech "deskowców” na terenie osiedla mieszkaniowego w rejonie ul. Chabrów ${ }^{17}$. W następnych latach powstawały kolejne osiedla mieszkaniowe na terenie miasta, $\mathrm{w}$ tym także na terenach nowo przyłączonych do Opola, jak Gosławice, Malina czy Grotowice (w tym ostatnim przy padku chodzi o osiedle związane z Zakładami Aparatury Chemicznej "Metalchem”).

$\mathrm{W}$ tym czasie $\mathrm{w}$ budownictwie mieszkaniowym zaczęła być $\mathrm{w}$ coraz większym stopniu stosowana przemysłowa technologia wielkiej płyty. Już w pierwszej połowie $1972 \mathrm{r}$. władze wojewódzkie zaczęły zabiegać o zlokalizowanie tzw. fabryki domów na terenie Opola, a także trzech polowych („poligonowych") wytwórni wielkopłytowych elementów budowlanych w rejonie Kędzierzyna, Nysy i Raciborza. Na bazie tych zakładów miały powstać kombinaty budownictwa mieszkaniowego ${ }^{18}$. Realizacja tych zamierzeń powiodła się jednak tylko częściowo i z wielkimi trudnościami. Budowa opolskiej „fabryki domów” ruszyła w trzecim kwartale 1974 r. ${ }^{19}$ Zakład ten osią-

\footnotetext{
${ }^{16}$ APO, KW PZPR w Opolu, 383, Plan pracy „Trybuny Opolskiej” na II kwartał 1974 r., s. 81.

17 Rosna mury największego budynku w Opolu. Mister naszego miasta?, "Trybuna Opolska”, 13 kwietnia 1972 r., s. 7.

${ }^{18}$ APO, KW PZPR w Opolu, 102, Wystąpienie tow. Władysława Bilińskiego, kierownika Wydziału Budownictwa KW - Załącznik nr 5 do Protokołu z plenarnego posiedzenia Komitetu Wojewódzkiego PZPR w Opolu, odbytego w dniu 13 kwietnia 1972 r., s. 66; tamże, [Wystąpienie Władysława Bilińskiego, kierownika Wydziału Budownictwa KW PZPR w Opolu, kwiecień 1972 r.], s. 243-244; tamże, Uchwała Komitetu Wojewódzkiego PZPR w Opolu w sprawie węzłowych problemów rozwoju przemysłu kluczowego [13 kwietnia1972 r.], s. 275; APO, KW PZPR w Opolu, 544, Notatka o problemach gospodarczych województwa opolskiego wymagających rozpatrzenia i podjęcia decyzji Rządu, 3 lipca 1972 r., s. 190.

${ }^{19}$ APO, KW PZPR w Opolu, 36, Przemówienie I sekretarza Komitetu Wojewódzkiego PZPR [w Opolu] na XIV Wojewódzkiej Konferencji Sprawozdawczo-Wyborczej w dniu 24 lutego 1975 r., s. 43; APO, KW PZPR w Opolu, 111, Sprawozdanie Komitetu Wojewódzkiego Polskiej Zjednoczonej Partii Robotniczej w Opolu za okres między XIII a XIV Konferencją Sprawozdawczo-Wyborczą (marzec 1973 - luty 1975 r.), styczeń 1975 r., s. 27; APO, KW PZPR w Opolu, 390, Sprawozdanie Komitetu Wojewódzkiego Polskiej Zjednoczonej Partii Robotniczej w Opolu za okres między XIII a XIV Konferencją Sprawozdawczo-Wyborczą (marzec 1973 luty 1975 r.), styczeń 1975 r., s. 13; APO, KW PZPR w Opolu, 392, Postanowienia nr 7/75 z posiedzenia Egzekutywy Komitetu Wojewódzkiego PZPR w Opolu, odbytego w dniu 3 kwietnia 1975 r., s. 75; tamże, Uwagi do „Informacji” o stanie realizacji Fabryk Domów w województwie opolskim, 24 marca 1975 r., s. 78-79; tamże, Notatka w sprawie podejmowanych decyzji nt. budowy fabryk domów w województwie opolskim, 24 marca 1975 r., s. 80-81; tamże, Informacja o stanie realizacji fabryk domów w Opolu i Nysie oraz przygotowania[ch] do realizacji fabryk domów w Kędzierzynie, Strzelcach Opolskich i Raciborzu na dzień 15 III 1975 r., marzec 1975 r., s. 83-95; APO, KW PZPR w Opolu, 396, Uwagi do „Informacji” o stanie realizacji fabryk domów w Opolu i Kędzierzynie, 10 lipca 1975 r., s. 45; tamże, Informacja o stanie realizacji fabryk domów w Opolu i Nysie na dzień 30 czerwca 1975 r., dokument z lipca 1975 r., s. 49-55.
} 
gnął zdolność produkcyjną z końcem marca 1976 r. W maju tego samego roku na ówczesnym Osiedlu Związku Walki Młodych (od 2008 r. osiedle Armii Krajowej) w dzielnicy Opole-Wschód, budowanym od 1975 r. pod patronatem Związku Socjalistycznej Młodzieży Polskiej, rozpoczęto montaż pierwszych budynków z elementów wielkopłytowych z tej wytwórni. W późniejszym czasie opolska „fabryka domów” zaopatrywała również rozpoczętą w 1976 r. budowę Osiedla Malinka ${ }^{20}$. Tuż przy historycznym centrum miasta, na wschód od niego, w rejonie obecnego pl. Teatralnego, powstało osiedle "Centrum".

Zgodnie z zatwierdzonym w 1960 r. planem zagospodarowania przestrzennego, miasto miało rozrastać się w kierunku wschodnim. Już w $1961 \mathrm{r}$. podjęto jednak sprzeczną $\mathrm{z}$ tym planem decyzję o rozbudowie miasta $\mathrm{w}$ kierunku przeciwnym, gdzie miała powstać dzielnica "Zachód”. Decyzję tę zaczęto realizować bez uprzedniego podjęcia niezbędnych zabiegów przygotowawczych na niedogodnych dla budownictwa, podmokłych terenach na dnie doliny Odry. Dopiero po negatywnych doświadczeniach, jakie przyniosła rozpoczęta w $1965 \mathrm{r}$. budowa zespołu szkół zawodowych w rejonie obecnej ul. Józefa Hallera i ul. Niemodlińskiej, odstąpiono od podjętych pochopnie decyzji, przerywając budowę osiedla "Zachód" i powracając do pierwotnych założeń planu ogólnego. Sytuacja zmieniła się jednak ponownie w latach siedemdziesiątych. Budownictwo mieszkaniowe wkroczyło wówczas szerokim frontem na dno doliny zalewowej Odry, na tereny nie tylko podmokłe i wymagające osuszenia, ale także pozbawione dostatecznej ochrony przed zagrożeniem powodziowym. Powstały wówczas nowe osiedla w rejonie ul. Szymona Koszyka i ul. Prószkowskiej oraz w rejonie ul. Łąkowej i ul. Stanisława Spychalskiego.

Rozwój budownictwa mieszkaniowego na terenie Opola służył nie tylko zaspokojeniu obiektywnych potrzeb mieszkańców, ale także realizacji politycznych ambicji ówczesnych włodarzy województwa, dla których poprawa sytuacji w stolicy regionu miała szczególnie duże znaczenie prestiżowe. Z tego powodu zaniedbywano inne części województwa, przeznaczając na rzecz Opola gros nakładów przeznaczonych na budownictwo mieszkaniowe $\mathrm{w}$ całym regionie. W początkach $1980 \mathrm{r}$. przypadało na ten ośrodek aż 43,4 proc. łącznej liczby mieszkań przewidzianych w planie wojewódz-

${ }^{20}$ APO, KW PZPR w Opolu, 404, Uwagi do informacji na temat oceny realizacji budowy fabryk domów w Opolu, Nysie i Kędzierzynie-Koźlu, czerwiec 1976 r., s. 32; tamże, Ocena realizacji budowy „fabryk domów” w Opolu, Nysie i Kędzierzynie-Koźlu [1976 r.], s. 35-37; tamże, Informacja w sprawie rozbudowy fabryki domów w Opolu, 31 maja 1976 r., s. 40; APO, KW PZPR w Opolu, 409, Informacja o ważniejszych inwestycjach dla gospodarki kraju i województwa opolskiego, maj 1977 r., s. 256-258; APO, KW PZPR w Opolu, 595, Informacja Opolskiego Kombinatu Budowlanego o aktualnym stanie produkcji fabryk domów w Opolu i Nysie Goświnowicach, [sierpień], s. 71. 
Opole. Zmiany granic miasta w latach 1974-1975

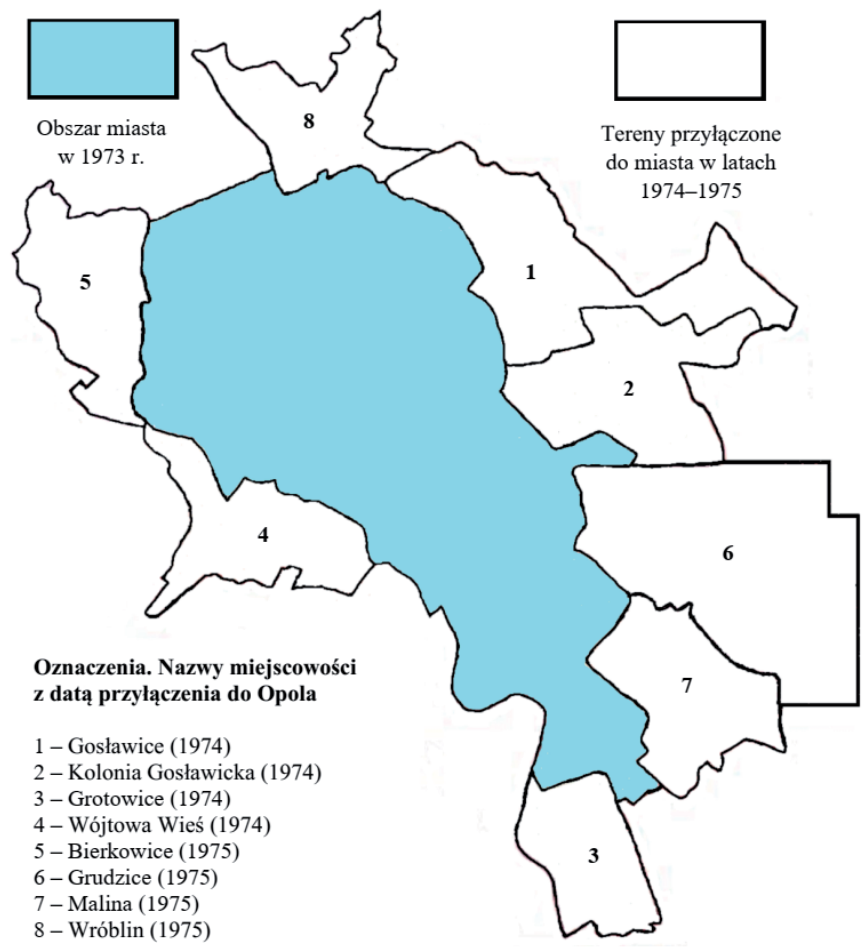

Ryc. 1. Zmiany granic administracyjnych Opola w latach w latach 1974-1975.

Opracowanie: Zbigniew Bereszyński

kim. Daleko w tyle znajdowały się inne ośrodki miejskie: Kędzierzyn-Koźle (9,0 proc.), Zdzieszowice (7,6 proc.), Nysa (5,7 proc.) i Brzeg (3,6 proc.). Na wszystkie pozostałe miejscowości przypadało łącznie 30,7 proc, mieszkań21. Przykład ten stanowi szczególnie jaskrawą i wymowną ilustrację negatywnego wpływu czynników politycznych na bieg procesów gospodarczych w czasach PRL.

$\mathrm{W}$ omawianym tu okresie Opole znacznie rozwinęło się także $\mathrm{w}$ sensie przestrzennym. Do połowy lat 70. XX w. obszar miasta powiększył się o szereg okolicznych wsi. W nowych granicach administracyjnych Opola znalazły się: Gosławice, Kolonia Gosławicka, Grotowice (1974), Bierkowice, Grudzice,

${ }^{21}$ APO, KW PZPR w Opolu, 427, Informacja o planie budownictwa mieszkaniowego, infrastruktury technicznej i społecznej na 1980 rok w świetle wykonania zadań N[arodowego] P[lanu] S[połeczno-]G[ospodarczego] bieżącej pięciolatki, 28 styczni 1980 r., s. 124. 
Malina, Wójtowa Wieś i Wróblin (1975). Powierzchnia miasta wzrosła w ten sposób do 96 km². W 1978 r. liczba mieszkańców Opola osiągnęła poziom 111300 osób $^{22}$. W 1985 r. przekroczyła już poziom 126 tys. osób ${ }^{23}$.

Wzrost liczby ludności był w dużej mierze efektem ruchów migracyjnych. Stałą tendencją w życiu społecznym Opola była duża przewaga liczby osób przybywających na stałe do miasta nad liczbą osób je opuszczających ${ }^{24}$. Ów pozytywny bilans migracyjny można łączyć z takimi zjawiskami jak inwestycje gospodarcze i związany $\mathrm{z}$ nimi wzrost liczby miejsc pracy w mieście oraz postępujący w tym samym czasie rozwój budownictwa mieszkaniowego. Zbliżony w sensie ilościowym efekt miały zmiany administracyjne, związane z powiększaniem obszaru miasta o kolejne wsie.

Lata siedemdziesiąte XX w. przyniosły znaczną rozbudowę bazy materialnej opolskich uczelni wyższych. W 1973 r. oddano do użytku nowy akademik Wyższej Szkoły Inżynierskiej przy ul. Oleskiej i rozpoczęto budowę nowego, dziesięciopiętrowego akademika Wyższej Szkoły Pedagogicznej (późniejszy Dom Studencki „Kmicic”). W tymże roku ruszyła również budowa rozległego campusu WSI przy ul. Oleskiej, obejmującego w szczególności Instytut Budowy Maszyn wraz z rektoratem. Kolejną ważną inwestycją była budowa gmachu Instytutu Chemii WSP przy ul. Oleskiej ${ }^{25}$. W 1975 r. oddano do użytku m.in. nową siedzibę Teatru im. Jana Kochanowskiego w Opolu oraz rzeźnię Opolskich Zakładów Drobiarskich ${ }^{26}$. W tym samym roku rozpoczęto m.in. budowę Elektrowni „Opole” w Brzeziu koło Opola oraz Chłodni Składowej w Opolu ${ }^{27}$.

\footnotetext{
${ }^{22}$ APO, UM w Opolu, 1801, Kroniki i monografie własne. Kronika miasta Opola 1980, s. 124.

${ }^{23}$ Zob. Z. Bereszyński, Opole polskie (1945-2010), [w:] Opole. Dzieje i tradycja, red. B. Linek, K. Tarka, U. Zajączkowska, Opole 2011, s. 107.

${ }^{24}$ Tak np. w latach 1971 i 1972 nadwyżka napływu nad odpływem wyniosła odpowiednio około 1100 i około 1200 osób. J. Kroszel, Ludność, [w:] Opole. Monografia miasta, red. W. Dziewulski i F. Hawranek, Opole 1975, s. 508.

${ }^{25} \mathrm{APO}, \mathrm{KW}$ PZPR w Opolu, 573, Informacja dot. realizacji inwestycji Szkolnictwa Wyższego i Techniki, 22 stycznia 1975 r., s. 105; K. Turwid, Owacje i frustracje. Opolskie budowanie 1945-2005, Opole 2006, s. 93.

${ }^{26}$ APO, KW PZPR w Opolu, 398, Informacja o realizacji Uchwały Plenum KW PZPR w Opolu z dnia 21 listopada 1973 r. w sprawie rozwoju kultury w województwie opolskim, 2 września 1975 r., s. 38; APO, KW PZPR w Opolu, 574, Postanowienia nr 8/75 z posiedzenia Sekretarzy Komitetu Wojewódzkiego PZPR w Opolu w dniu 11 lutego 1975 r., s. 42, 43; tamże, Uchwała Egzekutywy KW PZPR w Opolu w sprawie terminowej realizacji inwestycji szczególnie ważnych z planu centralnego i planu terenowego, [luty 1975 r.], s. 90.

${ }^{27} \mathrm{APO}, \mathrm{KW}$ PZPR w Opolu, 36, [Wystąpienie Jerzego Dorawy, robotnika z Huty Małapanew, na XIV Wojewódzkiej Konferencji Sprawozdawczo-Wyborczej, 24 lutego 1975 r.], s. 163; APO, KW PZPR w Opolu, 392, Informacja na temat bilansu robót budowlano-montażowych na 1975 r., b. d., s. 33-44; tamże, Wykaz inwestycji nowo rozpoczynanych na 1975 r. na terenie woj[ewództwa] opolskiego (bez rolnictwa), [luty 1975 r.], s. 51-53; APO, KW PZPR w Opolu, 573,
} 


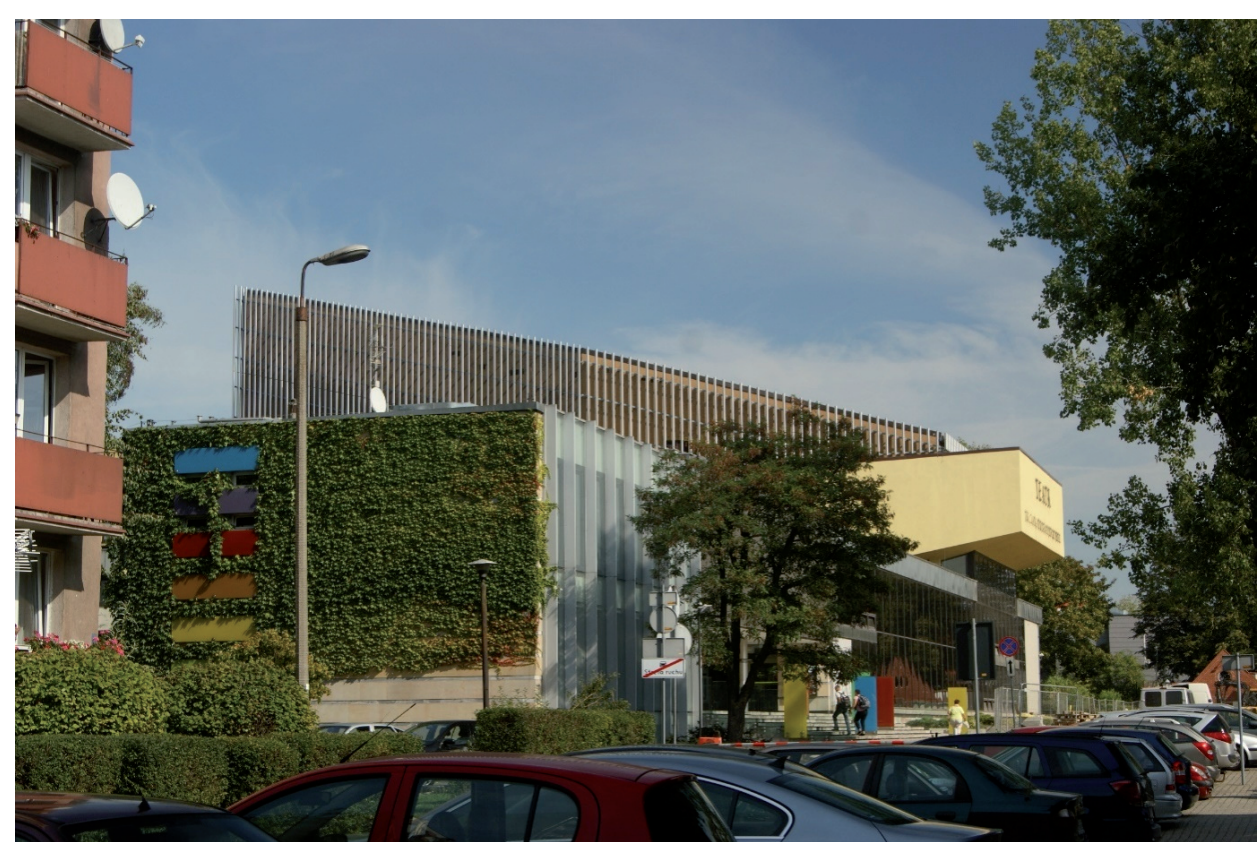

Il. 1. Teatr im. Jana Kochanowskiego w Opolu, oddany do użytku w 1975 r. Fot. Zbigniew Bereszyński

Tymczasem w całym kraju zaczęły narastać problemy z realizacją rozpoczętych zadań inwestycyjnych. Budowano zbyt wiele obiektów naraz w stosunku do posiadanych funduszy i mocy przerobowych. W 1974 r. nie udało się zrealizować planu rocznego w przypadku trzydziestu spośród trzydziestu siedmiu zadań zaliczanych do inwestycji ważnych dla województwa opolskiego. W lutym 1975 r. Sekretariat KW PZPR w Opolu zwrócił uwagę na „niewykonywanie planu przez przedsiębiorstwa budowlane, a głównie $\mathrm{w}$ budownictwie mieszkaniowym" ${ }^{28}$. Bardzo źle przedstawiała się również sytuacja na budowach nowej siedziby Instytutu Śląskiego oraz Instytutu Chemii WSP w Opolu, gdzie zaawansowanie robót wynosiło odpowiednio 21,0 i 21,8 proc. $^{29}$

Program rozwoju Opolskiego Przedsiębiorstwa Budownictwa Przemysłowego nr 2 w Opolu (założenia ogólne), 16 stycznia 1975 r., s. 90; APO, KW PZPR w Opolu, 583, Scenariusz uroczystego otwarcia Rzeźni Drobiu Opolskich Zakładów Drobiarskich, 4 sierpnia 1975 r., s. 96-97; APO, KW PZPR w Opolu, 590, Informacja, 10 marca 1976 r., s. 183.

${ }^{28}$ APO, KW PZPR w Opolu, 574, Postanowienia nr 5/75 z posiedzenia Egzekutywy Komitetu Wojewódzkiego PZPR w Opolu, odbytego w dniu 5 lutego 1975 r., s. 2.

${ }^{29}$ APO, KW PZPR w Opolu, 587, Realizacja ważniejszych zadań gospodarczych w okresie styczeń - październik 1975 r., 13 września 1975 r., s. 131. 
Mimo to nie rezygnowano z dalszego rozszerzania frontu inwestycyjnego. Już w 1973 r. zrodziła się koncepcja budowy Spółdzielczego Domu Usług - nowoczesnego kompleksu usługowego, mającego stanowić „wizytówkę spółdzielczości pracy województwa opolskiego. Obiekt ten postanowiono ulokować przy ul. Ozimskiej, co wiązało się z koniecznością częściowego wyburzenia starej zabudowy w tym rejonie. Zmiany organizacyjne oraz zmiana koncepcji zabudowy ul. Ozimskiej spowodowały jednak przesunięcie realizacji inwestycji na lata 1979-198130. Ostatecznie w czerwcu 1979 r. na posiedzeniu Egzekutywy KW PZPR zapadła decyzja o rozpoczęciu budowy „Domu Rzemiosła” - późniejszego Domu Handlowego „Rzemieślnik - po przeciwległej stronie ul. Ozimskiej ${ }^{31}$.

W 1974 r. listę nowo budowanych zakładów przemysłowych powiększyły wówczas m.in. dwa wielkie zakłady przemysłu rolno-spożywczego z siedzibą w Opolu: Opolskie Zakłady Drobiarskie (nowa rzeźnia drobiu w Opolu oraz wylęgarnia drobiu i ferma niosek w Niemodlinie) ${ }^{32}$. W następnym roku ruszyła budowa Zakładów Aparatury Chemicznej „Metalchem” w Grotowicach, $w$ granicach administracyjnych Opola, finansowana $z$ kredytu dewizowego w wysokości 20 mln dolarów, udzielonego przez Międzynarodowy Bank Współpracy Ekonomicznej w Moskwie ${ }^{33}$.

W styczniu 1975 r. Sekretariat KW PZPR postanowił „wprowadzić dodatkowo poza planem do realizacji w roku 1975 budowę" nowego centrum handlowego w rejonie ówczesnego Placu Lenina w Opolu. Z uwagi na zaliczenie

${ }^{30} \mathrm{APO}, \mathrm{KW}$ PZPR w Opolu, 622, Informacja o przygotowaniu do realizacji inwestycji „Dom Usług Spółdzielczych" w Opolu, [1978 r.], s. 197-198. Obiekt ten miał być zbudowany po północnej stronie ul. Ozimskiej, pomiędzy tą ulicą a ul. Studzienną.

${ }^{31}$ APO, KW PZPR w Opolu, 423, Protokół nr XII/79 z posiedzenia Egzekutywy KW PZPR w Opolu, odbytego 21 czerwca 1979 r., s. 155.

${ }_{32}$ APO, KW PZPR w Opolu, 36, Referat Egzekutywy KW PZPR [w Opolu] z dnia 15 stycznia 1975 r. o sytuacji gospodarczej Opolszczyzny, s. 353-354; APO, KW PZPR w Opolu, 110, Kierunki rozwoju rolnictwa i przemysłu rolno-spożywczego województwa opolskiego do roku 1980, listopad 1974 r., s. 321-322; APO, KW PZPR w Opolu, 112, Ocena modernizacji przemysłu województwa opolskiego w latach 1971-1975, czerwiec 1976 r., s. 126-127; APO, KW PZPR w Opolu, 378, Opolskie Przedsiębiorstwo Budownictwa Przemysłowego nr 2, 13 sierpnia 1973 r., s. 43, 45; APO, KW PZPR w Opolu, 389, Wnioski kadrowe przedłożone na Egzekutywie KW PZPR w dniu 4 lipca 1974 r., s. 45; APO, KW PZPR w Opolu, 389, Informacja o realizacji niektórych zadań gospodarczych w 1974 r. (dane wstępne), 7 stycznia 1975 r., s. 15; APO, KW PZPR w Opolu, 588, Informacja o stanie inwestycji na dzień 31 października 1975 r., s. 17; APO, KW PZPR w Opolu, 577, Informacja z przebiegu budowy Zakładów Drobiarskich w Opolu, 10 marca 1975 r., s. 124; tamże, Informacja o przebiegu budowy Zakładów Mięsnych w Opolu, 10 marca 1975 r., s. 127; APO, KW PZPR w Opolu, 588, Informacja w sprawie realizacji przedsięwzięcia inwestycyjnego pt. Kombinat Mięsny w Opolu, 27 listopada 1975 r., s. 132.

${ }_{33}$ APO, KW PZPR w Opolu, 42, Przemówienie [I sekretarza KW PZPR, Andrzeja Żabińskiego] wygłoszone na Wojewódzkiej Konferencji Sprawozdawczo-Wyborczej PZPR w Opolu w dniu 22 grudnia 1979 r., s. 27. 
tego przedsięwzięcia do szczególnie ważnych zadań inwestycyjnych nadzór nad budową miał sprawować osobiście I sekretarz KW PZPR, A. Żabiński. Rzecz znamienna, uznano, że sprawa ta nie powinna być tematem "publikacji w środkach masowego przekazu"34. W maju 1975 r. Rada Ministrów wykreśliła budowę centrum handlowego w Opolu z planu inwestycyjnego na tenże rok. Mimo to władze wojewódzkie postanowiły przystąpić do realizacji tego przedsięwzięcia jeszcze w $1975 \mathrm{r}^{35}$ Zamierzano w ten sposób wykreować nowe centrum polityczne, kulturalne i handlowe województwa i jego stolicy: nowy dom towarowy miał powstać w bliskim sąsiedztwie siedziby KW PZPR i oddanej do użytku w 1975 r. nowej siedziby teatru ${ }^{36}$.

31 sierpnia 1976 r. na posiedzeniu Sekretariatu KW PZPR zaakceptowano projekt wyburzenia starego browaru wraz z sąsiednią zabudową $\mathrm{w}$ rejonie ówczesnego pl. Armii Czerwonej (obecnie pl. Mikołaja Kopernika) i zbudowania w tym miejscu olbrzymiego zespołu usługowo-handlowego wraz z zespołem administracyjnym, stanowiącego dopełnienie centralnego zespołu o podobnym charakterze $\mathrm{w}$ rejonie ówczesnego pl. Lenina (obecnie pl. Teatralny). Planowany obiekt miał mieć charakter wielofunkcyjny, obejmujący "handel, usługi, gastronomię, kulturę i administrację". Na dwóch dolnych kondygnacjach obiektu miało mieścić się centrum usługowo-handlowe. Kondygnacje od trzeciej do siódmej miały być przeznaczone na część administracyjną ${ }^{37}$. Zamierzenia te miały przyczynić się do „ukształtowania centralnego ośrodka usługowego, złożonego z poszczególnych elementów usługowych”, tworzących ciągi „,w Rynku, przy ul. Krakowskiej, Ozimskiej, przy pl. Lenina i m.in. przy pl. Armii Czerwonej" 38 .

Strategia dynamicznego rozwoju załamała się ostatecznie w latach 19761977. Brakowało środków niezbędnych do realizacji zaplanowanych wcześniej przedsięwzięć, a podaż towarów i usług nie dorównywała popytowi,

${ }^{34}$ APO, KW PZPR w Opolu, 574, Notatka, 4 II 1975 r., s. 98; APO, KW PZPR w Opolu, 572, Postanowienia nr 2/75 z posiedzenia Egzekutywy Komitetu Wojewódzkiego PZPR w Opolu w dniu 14 stycznia 1975 r., s. 76-78; tamże, Informacja na temat budowy Centrum Handlowego w Opolu, 8 stycznia 1975 r., s. 91-94.

${ }^{35}$ APO, KW PZPR w Opolu, 396, Ważniejsze zadania inwestycyjne, które powinny być realizowane w najbliższych latach w m. Opolu, czerwiec 1975 r., s. 11; APO, KW PZPR w Opolu, 582, Informacja, 7 lipca 1975 r., s. 74.

${ }^{36}$ Zob. A. Hamada, Opolski Biaty Dom, „Indeks. Pismo Uniwersytetu Opolskiego” 2005, nr 3-4, s. 48.

${ }^{37}$ APO, KW PZPR w Opolu, 595, Postanowienie nr 32/76 z posiedzenia Sekretariatu Komitetu Wojewódzkiego PZPR, odbytego 31 sierpnia 1976 r., s. 131; tamże, Notatka w sprawie programu budowy zespołu usługowo-administracyjnego w rejonie Pl. Czerwonej Armii, 27 sierpnia 1976 r., s. 172-174. Notatkę w tej sprawie przedłożył I sekretarz Komitetu Miejskiego PZPR w Opolu, Henryk Stachowiak.

38 APO, KW PZPR w Opolu, 615, Uzasadnienie propozycji realizacji ośrodka usługowego w Opolu na terenie „po browarze” przy pl. Armii Czerwonej, [1978 r.], s. 137. 
związanemu z nadmierną emisją pieniądza ${ }^{39}$. Podjęta w czerwcu 1976 r. próba opanowania sytuacji gospodarczej na zasadzie podwyżki cen zakończyła się fiaskiem - władze państwowe musiały dać za wygraną w obliczu robotniczych protestów ${ }^{40}$. W związku z tym zrodziła się konieczność przeznaczenia większych środków na przedsięwzięcia służące zaspokojeniu potrzeb konsumpcyjnych społeczeństwa ze szkodą dla inwestycji w sferze produkcyjnej. Władze PRL zmuszone były zastosować tzw. manewr gospodarczy, polegający w szczególności na skróceniu frontu inwestycyjnego i zmianie kierunków inwestycji ${ }^{41}$.

Konsekwencje "manewru gospodarczego” dały znać o sobie również w przypadku Opola. Część planowanych bądź podjętych już przedsięwzięć inwestycyjnych zaniechano, co w niejednym przypadku wiązało się z marnotrawstwem poniesionych nakładów. Inne realizowano z wielkimi trudnościami i znacznym opóźnieniem.

Rozpoczętej w 1975 r. budowy opolskiego „Metalchemu” nigdy nie doprowadzono do końca. W referacie wygłoszonym w lutym 1977 r. przez I sekretarza KW PZPR, A. Żabińskiego, podawano ją jako przykład szczególnie źle realizowanej inwestycji ${ }^{42}$. W grudniu 1979 r. znów była mowa o opóźnieniach $\mathrm{w}$ jej realizacji ${ }^{43}$. Wznoszony dla opolskiego "Metalchemu” wieżowiec administracyjny pozostał nie ukończony i ostatecznie całkowicie go rozebrano ${ }^{44}$.

Zapoczątkowana w tym samym czasie budowa domu handlowego „Opolanin" w centrum miasta, z uwagi na niedostatek materiałów, rąk do pracy itp., ciągnęła się aż do 1983 r., a okres, w jakim oddano do użytku nowy obiekt (niedługo po zniesieniu stanu wojennego), nie sprzyjał już propagandowemu zdyskontowaniu tego wydarzenia. Nowy dom towarowy był przestarzały już w chwili oddawania go do użytku, a wkrótce potem zaczęły się problemy z rozmaitymi usterkami i błędami wykonania. Historia tej monumentalnej budowli zakończyła się po dwudziestu latach zamknięciem obiek-

${ }^{39}$ M. Krajewski, Historia gospodarcza Polski do 1989 roku. Zarys problematyki, Włocławek 2000, s. 502 .

40 Zob. P. Sasanka, dz. cyt., s. 166-261, 416-417; W. Roszkowski, Najnowsza historia Polski 1945-1980, Warszawa 2003, s. 698-703; A.L. Sowa, dz. cyt., s. 407-411.

${ }^{41}$ G. Kołodko, Polska w świecie inflacji, Warszawa 1987, s. 184-185; M. Krajewski, dz. cyt., s. 503-504; M. Bałtowski, Gospodarka socjalistyczna w Polsce, Warszawa 2009, s. 242-243.

42 APO, KW PZPR w Opolu, 113, Wprowadzenie do dyskusji na posiedzenie Komitetu Wojewódzkiego [PZPR] na temat "Jakość pracy i wytwarzania w gospodarce województwa opolskiego" w dn. 23 lutego 1977 r., [luty 1977 r.], s. 61.

43 APO, KW PZPR w Opolu, 42, Przemówienie [I sekretarza KW PZPR, Andrzeja Żabińskiego] wygłoszone na Wojewódzkiej Konferencji Sprawozdawczo-Wyborczej PZPR w Opolu w dniu 22 grudnia 1979 r., s. 27.

44 Zob. K. Turwid, dz. cyt., s. 48-49, 71, 115. 


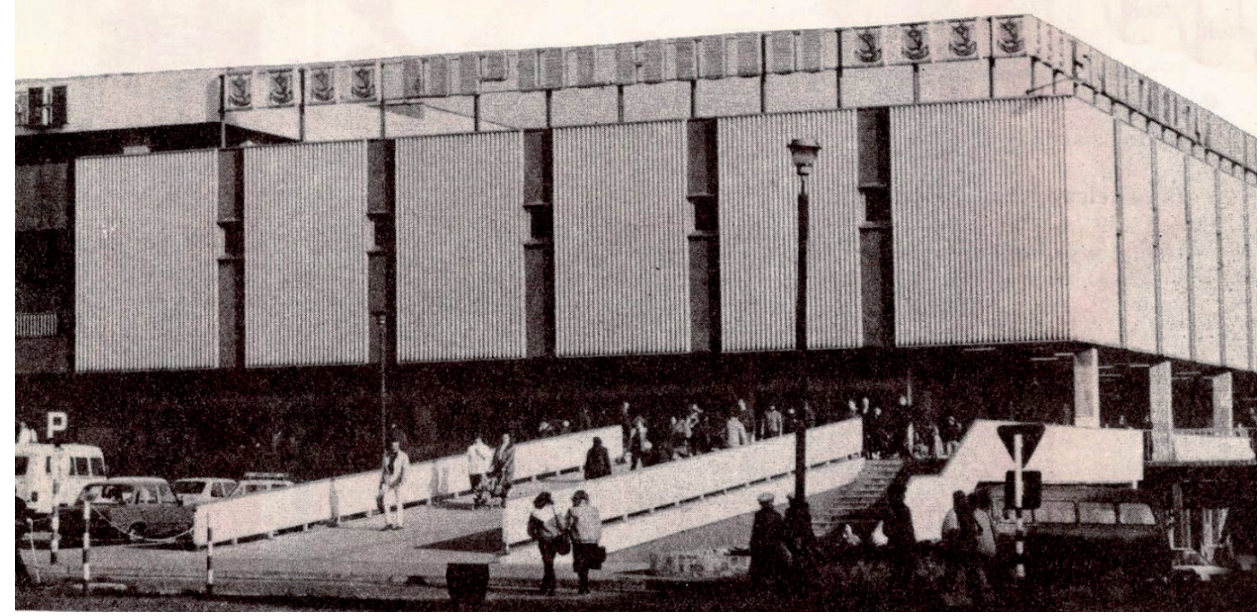

Il. 2. Dom handlowy „Opolanin”. Fotografia archiwalna.

Źródło: domena publiczna

tu, który w 2003 r. postanowiono przebudować na nowoczesną galerię handlową ${ }^{45}$.

W lutym 1977 r. Sekretariat KW PZPR podjął decyzję o pełnym wyburzeniu dawnego browaru przy pl. Kopernika wraz z sąsiednią zabudową ${ }^{46}$. W ten sposób doszło do zniszczenia jednego z najokazalszych zabytków budownictwa technicznego na terenie Opola. Zabrakło natomiast funduszy na planowaną budowę wielkiego zespołu usługowo-handlowo-administracyjnego w tym miejscu. W środku miasta powstała wielka, pusta przestrzeń, na której zagospodarowanie w czasach PRL nigdy już nie znaleziono środków ${ }^{47}$. Idea zbudowania $\mathrm{w}$ tym miejscu wielkiego centrum usługowo-handlowego została zrealizowana dopiero $\mathrm{w}$ następnym tysiącleciu.

45 Opolanin - 20 lat minęto, „Nowa Trybuna Opolska” z 17 października 2003 r., s. 10.

${ }^{46}$ APO, KW PZPR w Opolu, 601, Protokół nr 6/77 z posiedzenia Sekretariatu Komitetu Wojewódzkiego PZPR w Opolu w dniu 8 lutego 1977 r., s. 67. I sekretarza KM PZPR uczyniono odpowiedzialnym za wykonanie tej decyzji do 15 kwietnia 1977 r., ale jeszcze w lutym Sekretariat KW przesunął termin rozpoczęcia robót rozbiórkowych na sierpień tegoż roku. Tamże, Protokół nr 8/77 z posiedzenia Sekretariatu Komitetu Wojewódzkiego PZPR w Opolu z 22 lutego 1977 r., s. 173. Wyburzenia objęły także inne części miasta. Tylko w okresie do końca lipca 1978 r. rozebrano łącznie ponad trzydzieści obiektów. APO, KW PZPR w Opolu, 417, Realizacja postanowień z posiedzenia Egzekutywy KW PZPR i KM PZPR w Opolu z 14 lipca 1978 r., dokument z sierpnia 1978 r., s. 109.

47 Zob. E. Matuszczyk, Z przeszłości placu Kopernika, „Almanach miejski. Opolanin” 2001, s. 39 . 


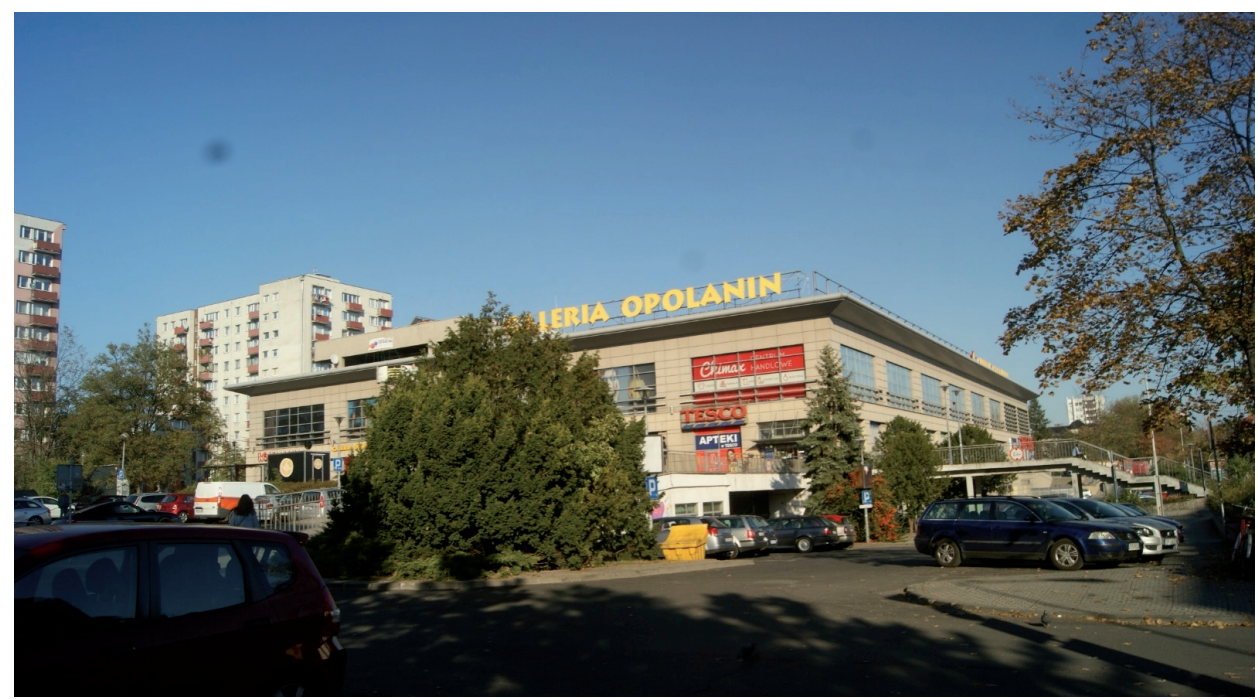

Il. 3. Nowoczesna galeria handlowa „Opolanin”.

Fot. Zbigniew Bereszyński

Od listopada 1972 r. trwała budowa nowej siedziby Instytutu Śląskiego przy ul. Piastowskiej ${ }^{48}$. Według oceny zawartej $w$ referacie przygotowanym na wrześniowe plenum KW PZPR w tymże roku, budowa posuwała się jednak „W żółwim tempie"49. W myśl pierwotnych planów obiekt ten, zaprojektowany jako ośmiokondygnacyjny biurowiec, miał być oddany do użytku w czerwcu 1975 r. ${ }^{50}$ Niestety realizacja inwestycji zaczęła się opóźniać z powodu błędów w dokumentacji, a także w związku z wadliwym wykonaniem prefabrykatów budowlanych ${ }^{51}$. W marcu $1976 \mathrm{r}$. budynek w stanie surowym był gotowy w 70 proc $^{52}$. Latem tegoż roku bliżej nieokreślone gremium zadecydowało jednak o zmianie przeznaczenia budynku, nazywanego domem

${ }^{48}$ APO, Akta Komitetu Miasta i Powiatu PZPR w Opolu, 50/IV/66, Ocena realizacji procesu inwestycyjnego w 1973 r. na terenie miasta i powiatu opolskiego, [luty 1974 r.], b.p.

${ }^{49}$ APO, KW PZPR w Opolu, 104, Referat na Plenum KW PZPR o działalności ideowo-wychowawczej partii w zakładach pracy województwa opolskiego, wrzesień 1972 r., s. 160; APO, KW PZPR w Opolu, 107, Uchwała nr 10 Komitetu Wojewódzkiego PZPR w Opolu. O większą efektywność działania partyjnych szeregów w realizacji zadań społeczno-gospodarczych w 1973 r., 15 stycznia 1973 r., s. 98.

${ }^{50}$ APO, KW PZPR w Opolu, 383, Informacja o realizacji Uchwały KW [PZPR] nr 3/72 w sprawie pracy Instytutu Śląskiego w Opolu, [kwiecień 1974 r.], s. 59.

${ }^{51}$ APO, KW PZPR w Opolu, 110, Ocena wyników działalności społeczno-gospodarczej i partyjno-politycznej w I półroczu i zadania w tych dziedzinach na II półrocze 1974 r., lipiec 1974 r., s. 33; APO, KW PZPR w Opolu, 573, Informacja dot. realizacji inwestycji Szkolnictwa Wyższego i Techniki, 22 stycznia 1975 r., s. 105.

52 APO, KW PZPR w Opolu, 591, Informacja o stanie realizacji inwestycji WSI, WSP i Instytutu Śląskiego w Opolu dla Sekretariatu KW PZPR, 15 marca 1976 r., s. 67. 


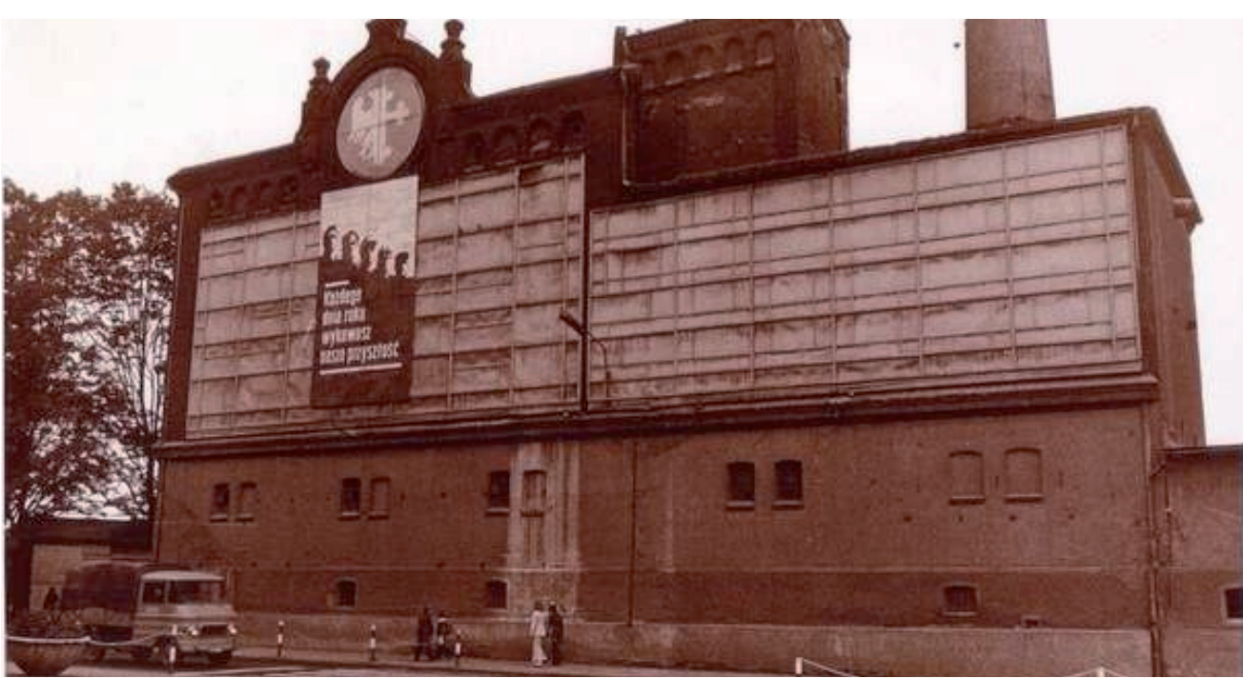

Il. 4. Browar w Opolu. Fotografia archiwalna.

Źródło: domena publiczna

społecznym, postanawiając, że będzie się w nim mieścić siedziba Komitetu Wojewódzkiego i Komitetu Miejskiego PZPR. Pociągnęło to za sobą istotne zmiany w projekcie o charakterze rozszerzającym, wraz z koniecznością wyburzenia sąsiednich budynków ${ }^{53}$. W ten sposób interesy aparatu partyjnego zostały postawione ponad potrzebami miejscowego środowiska naukowego.

Realizacja skorygowanego projektu przebiegała jednak z wielkimi trudnościami. Napotykano na takie, trudne do przezwyciężenia w ówczesnych realiach gospodarczych, problemy jak np. „brak przydziału konstrukcji stalowej w ilości 400 ton" $^{\prime 54}$. Gdy w latach 1980-1981 w Instytucie Śląskim narodziła się zakładowa organizacja NSZZ "Solidarność”, budowa „domu społecznego" była jeszcze w toku. Dzięki temu związkowcy, na czele ze Stanisławem Jałowieckim, we współpracy z instytutową organizacją PZPR, na czele z Januszem Sawczukiem, mogli podjąć uwieńczoną powodzeniem walkę o zagospodarowanie tego obiektu zgodnie z pierwotnym przeznaczeniem. Oddane do użytku w 1983 r. pomieszczenia "domu społecznego" zostały zagospodarowane w większości przez Instytut Śląski (gmach główny), a częściowo przez Wyższą Szkołę Pedagogiczną w Opolu. W pomieszczeniach tych została ulokowana m.in. Biblioteka Główna WSP, dla której

${ }^{53}$ APO, KW PZPR w Opolu, 595, Notatka, 30 sierpnia 1976 r., s. 175-177. Przywołana tu notatka została sporządzona przez Wydział Ekonomiczny i Ogólny KW PZPR w Opolu.

${ }^{54}$ APO, KW PZPR w Opolu, 620, Informacja o dotychczasowej realizacji przyszłych pomieszczeń dla Komitetu Wojewódzkiego i Miejskiego PZPR w Opolu przy ul. Piastowskiej, 16 sierpnia 1978 r., s. 27-29. 


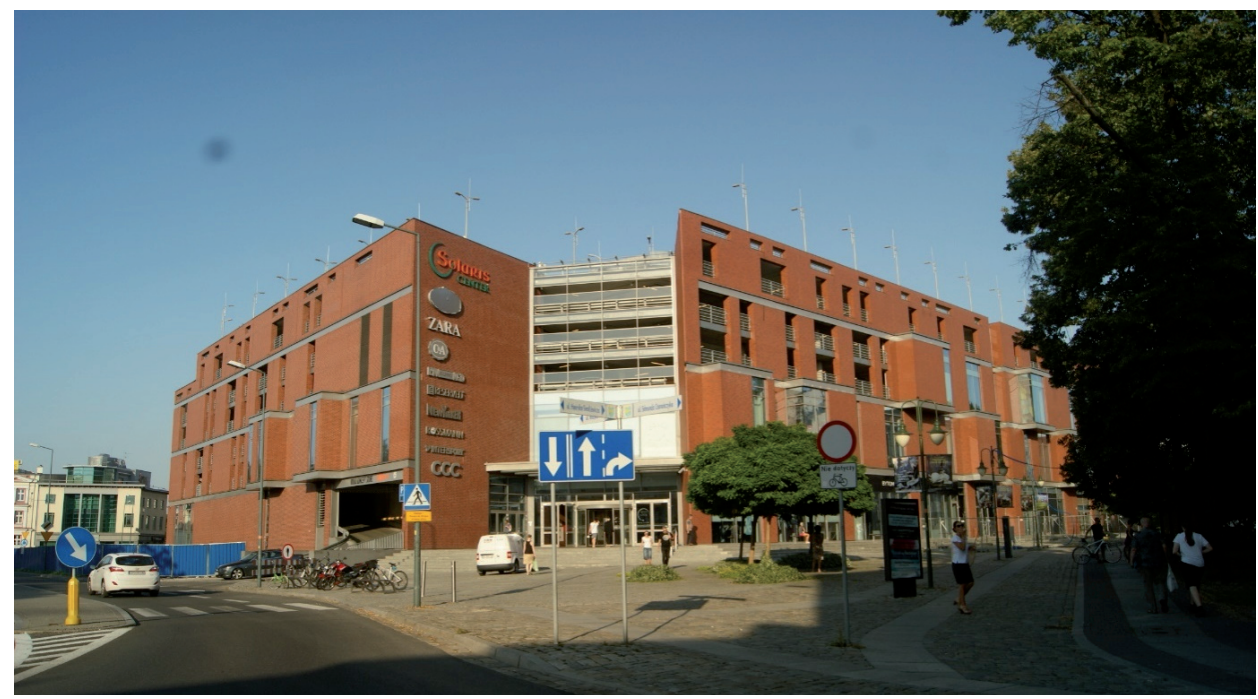

Il. 5. Galeria handlowa „Solaris", zbudowana na miejscu dawnego browaru.

Fot. Zbigniew Bereszyński

w latach siedemdziesiątych zamierzano wybudować nową siedzibę, ale brak środków nie pozwolił na realizację tych zamierzeń ${ }^{55}$.

Odczuwalny dotkliwie w drugiej połowie lat 70. niedostatek środków finansowych przesądził w negatywny sposób także o losach planowanej od wielu lat stałej ekspozycji archeologicznej na Ostrówku. W listopadzie 1979 r. Sekretariat KW PZPR uznał, że priorytetem jest wykonanie zadaszenia nad sceną sąsiedniego amfiteatru ${ }^{56}$. Do sprawy ekspozycji reliktów grodu już więcej nie powracano, także po upadku systemu komunistycznego w Polsce ${ }^{57}$.

Istotne miejsce w planach przebudowy Opola zajmowała sprawa modernizacji układu komunikacyjnego miasta. Przewidywano, że w związku z rozwojem motoryzacji miastu grozi „wielki korek”. Wobec tego projektowano

${ }^{55}$ Zob. Z. Bereszyński, Instytut Śląski w Opolu w czasach rewolucji solidarnościowej (w świetle dokumentów sprawy obiektowej krypt. „Silesia”), cz. I, „Indeks. Pismo Uniwersytetu Opolskiego” 2007, nr 9-10, s. 29.

${ }^{56}$ APO, KW PZPR w Opolu, 622, Protokół nr 45/78 z posiedzenia Sekretariatu KW PZPR w Opolu w dniu 14 listopada 1978 r., s. 33.

57 „Należy mieć nadzieję, że idea ta jednak spotka się wreszcie z należytym zrozumieniem i zostaną stworzone warunki dla jej realizacji" - pisał przed laty Bogusław Gediga. Słowa te pozostają nadal aktualne. B. Gediga, Badania i dzieje wczesnośredniowiecznego grodu na Ostrówku w Opolu, [w:] Opole. Gród, miasto, stolica regionu. Materiaty z sesji popularnonaukowej zorganizowanej w Opolu 28 maja 1993 r., Opole 2002, s. 18-19. 


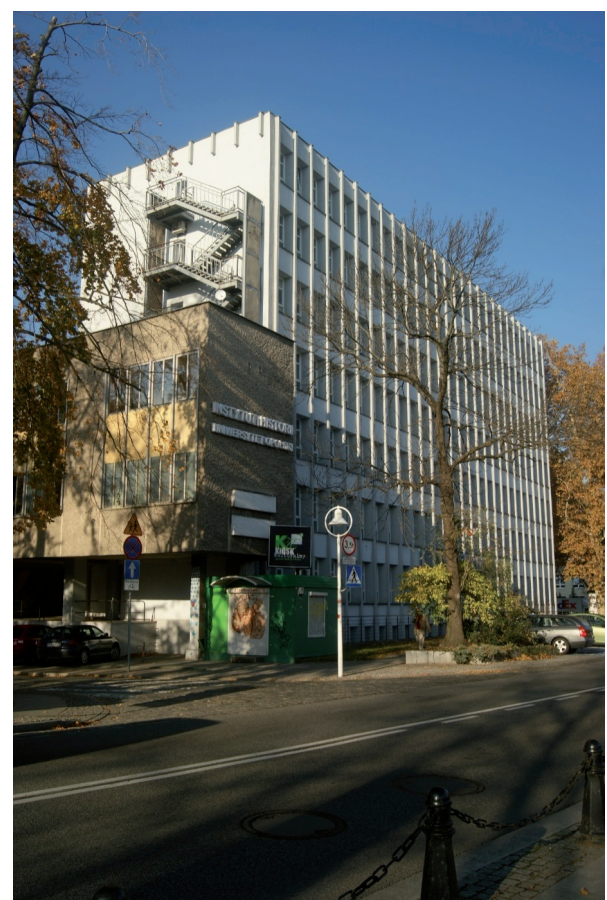

Il. 6. Gmach Instytutu Śląskiego.

Fot. Zbigniew Bereszyński budowę obwodnicy ${ }^{58}$. W czerwcu 1978 r. Sekretariat KW PZPR „zaakceptował informację na temat realizacji drogi obwodowej miasta Opola" 59 . W grudniu tegoż roku Wydział Ekonomiczny KW PZPR zaaprobował przedłożoną przez wicewojewodę Mieczysława Basińskiego informację o zamierzonych przedsięwzięciach $\mathrm{w}$ zakresie „modernizacji układu komunikacyjnego trasy E-22, budowy obwodnicy miasta Opola i autostrady". Przedsięwzięcia te miały obejmować w szczególności budowę dodatkowego mostu stalowego przez Odrę (obok istniejącego już mostu na przedłużeniu ul. Niemodlińskiej, celem rozdzielenia kierunków ru$\mathrm{chu}$ ), związaną $\mathrm{z}$ tym budowę wiaduktu nad ul. Bończyka, poszerzenie ul. Wrocławskiej do czterech pasów ruchu (na odcinku od ul. Niemodlińskiej do ul. Domań-

skiego), budowę estakady nad Rondem łącznie z przebudową ronda na osi ul. Niemodlińskiej i Nysy Łużyckiej, a także budowę estakady nad ul. Wrocławską na osi ul. Niemodlińskiej. Decydując się na budowę obwodnicy, „przyjęto koncepcję obejścia miasta od strony północnej”. Rozpoczęta w 1977 r. budowa autostrady na odcinku Gliwice - Wrocław miała być, według ówczesnych planów, ukończona w 1985 r. ${ }^{60}$

Zamierzenia te udało się zrealizować tylko częściowo. Zbudowano nowy most przez Odrę wraz z wiaduktem nad ul. Norberta Bończyka oraz estakadę nad przebudowanym Rondem (obecnym pl. Konstytucji 3 Maja). Na zbu-

58 APO, KW PZPR w Opolu, 383, Plan pracy „Trybuny Opolskiej” na II kwartał 1974 r., s. 81.

${ }^{59}$ APO, KW PZPR w Opolu, 617, Protokół nr 25/78 z posiedzenia Sekretariatu KW PZPR w Opolu w dniu 27 czerwca 1978 r., s. 166.

${ }^{60}$ APO, KW PZPR w Opolu, 417, Uchwała nr XLIX/78 dot. Informacji o modernizacji układu komunikacyjnego trasy E-22, budowy obwodnicy miasta Opola i autostrady, grudzień 1978 r., s. 108-109; tamże, Informacja o modernizacji układu komunikacyjnego trasy E-22, budowy obwodnicy miasta Opola i autostrady, listopad 1978 r., s. 111-115. 
dowanie autostrady i obwodnicy północnej Opola trzeba było jednak czekać jeszcze około trzydziestu lat.

W latach 1977-1979 wojewódzkie władze PZPR rozważały także koncepcję wykorzystania kolei dla rozwiązania problemów komunikacyjnych w centrum Opola. Koncepcja ta przewidywała wytworzenie połączenia kolejowego pomiędzy zespołami przemysłowymi we wschodniej części miasta a terenami mieszkaniowymi w części zachodniej, po przeciwległej stronie Odry. Cel ten zamierzano osiągnąć w szczególności poprzez rozbudowę „istniejącego układu torowego w celu uzyskania zamkniętej pętli z wykorzystaniem odcinka linii średnicowej Opole Wschód". Pętla taka miałaby połączyć ze sobą stacje Opole Wschód i Opole Zachód ${ }^{61}$. W warunkach szybko pogłębiającego się kryzysu gospodarczego w Polsce nie próbowano jednak realizować tej koncepcji.

Polityka inwestycyjna z lat 1971-1980 znacznie przeobraziła społecznogospodarcze oblicze stolicy województwa opolskiego. Miasto rozrosło się $\mathrm{w}$ sensie przestrzennym i demograficznym. Wzbogaciło się o wiele nowych mieszkań i miejsc pracy. W 1970 r. w różnych przedsiębiorstwach „gospodarki uspołecznionej" w Opolu pracowały łącznie 53104 osoby, dziewięć lat później było ich już 17800 więcej. Liczba lokali mieszkalnych w mieście wzrosła z 23668 do 36 583, a łączna liczba izb w tych mieszkaniach z 73604 do $111710^{62}$.

W latach 1978-1979 warunki życia w Opolu znacznie poprawiły się w wyniku zamknięcia cementowni „,Bolko” i „Piast”, których działalność była przez wiele lat źródłem uciążliwego zapylenia. Było to możliwe dzięki rozpoczęciu działalności przez nowo zbudowane cementownie w rejonie Strzelec Opolskich i Górażdży ${ }^{63}$.

Inwestycje zapoczątkowane $\mathrm{w}$ tym czasie przyniosły ostatecznie znaczną poprawę warunków działalności obu opolskich uczelni wyższych oraz

${ }^{61} \mathrm{APO}, \mathrm{KW}$ PZPR w Opolu, 410, Uchwała Komitetu Wojewódzkiego PZPR w Opolu z czerwca 1977 r. w sprawie: dalszego zaspokojenia potrzeb społecznych w zakresie budownictwa mieszkaniowego w województwie opolskim (projekt), s. 56; APO, KW PZPR w Opolu, 605, Kierunki działania instancji i organizacji partyjnych, Urzędów Miast i Gmin oraz instytucji i zakładów pracy w sprawie maksymalnego zaspokojenia dla ludności potrzeb mieszkaniowych w woj[ewództwie] opolskim do roku 1980 zgodnie z Uchwałami VIII Plenum KC PZPR, [czerwiec 1977 r.], s. 187; APO, KW PZPR w Opolu, 629, Informacja o możliwościach rozwoju szybkiej komunikacji zbiorowej w miastach: Opole, Kędzierzyn-Koźle, Nysa, wrzesień 1979 r., s. 253-254, 257.

${ }^{62}$ APO, UM w Opolu, 1801, Kroniki i monografie własne. Kronika miasta Opola 1980, s. 124.

${ }^{63}$ APO, KW PZPR w Opolu, 38, [Referat wygłoszony przez I sekretarza KW PZPR. Andrzeja Żabińskiego, na XVI Wojewódzkiej Konferencji Sprawozdawczo-Wyborczej PZPR w Opolu, 21 stycznia 1978 r.], s. 71-72; APO, KW PZPR w Opolu, 612, Projekt uchwały [Egzekutywy KW PZPR w Opolu], 24 listopada 1977 r., s. 69. 
Instytutu Śląskiego. Trwałą zdobyczą miasta stał się również nowoczesny budynek Teatru im. Jana Kochanowskiego, wykorzystywany z powodzeniem do chwili obecnej. W skali regionalnej ogromne znaczenie pozytywne miała m.in. doprowadzona ostatecznie do szczęśliwego końca budowa nowoczesnego szpitala wojewódzkiego. To samo można powiedzieć o ciągnącej się przez wiele lat budowie Elektrowni "Opole”.

Rozwój społeczno-gospodarczy Opola ${ }^{64}$ był jednak wybitnie nierównomierny, co było zresztą zjawiskiem charakterystycznym dla całego procesu przemian związanych z realizacją strategii dynamicznego rozwoju kraju. Tak np. szybkiemu wzrostowi liczby mieszkańców i samochodów ${ }^{65}$ nie dorównywał rozwój sieci drogowej w granicach miasta, ze szczególnym uwzględnieniem przepraw przez Odrę. Znaczna część nowych osiedli mieszkaniowych powstała w zachodniej części miasta, na terenach lewobrzeżnych, natomiast nowe miejsca pracy powstawały głównie na terenach prawobrzeżnych. Zdecydowanie zbyt mało zrobiono jednak dla ułatwienia komunikacji pomiędzy terenami leżącymi po przeciwległych stronach rzeki. Zbudowano wprawdzie nowe mosty nad Odrą oraz nad Kanałem Ulgi, biegnącym równolegle do rzeki po jej zachodniej stronie, ale liczba prowadzących przez Odrę ciągów komunikacyjnych dla ruchu kołowego pozostała bez zmian (tylko dwa takie ciągi w granicach miasta). Konsekwencją tych zaniedbań stały się występujące po dziś dzień ogromne problemy komunikacyjne.

W latach 1971-1980 i później zmarnowano ogromną ilość środków finansowych i materialnych na przedsięwzięcia, których nigdy w pełni nie sfinalizowano bądź doprowadzono do końca z dużym opóźnieniem. Podobne konsekwencje miała konieczność usuwania różnego rodzaju usterek związanych nieprawidłową realizacją poszczególnych inwestycji.

Z upływem czasu w dotkliwy sposób zemścił się woluntaryzm cechujący część decyzji związanych z inwestycjami na terenie miasta. Tak np. w wyniku wielkiej powodzi w lipcu 1997 r. znacznie ucierpiały osiedla mieszkaniowe wzniesione dwie dekady wcześniej na terenach zalewowych po zachodniej stronie Odry ${ }^{66}$.

Jak widać na tych przykładach, inwestycje z lat 1971-1980, oprócz oczywistych korzyści dla miasta, zrodziły również szereg poważnych problemów społecznych. Dziedzictwo to w niejednym przypadku nadal jeszcze bardzo ciąży miastu i jego mieszkańcom.

${ }^{64}$ Pod pojęciem rozwoju rozumiem postępujący stopniowo proces przemian służących coraz lepszemu zaspokojeniu potrzeb społecznych.

${ }^{65}$ W 1970 r. krążyły po Opolu 2433 samochody osobowe. W 1980 r. szacowano ich liczbę już na dziesięć do trzydziestu tysięcy. APO, UM w Opolu, 1801, Kroniki i monografie własne. Kronika miasta Opola 1980, s. 125.

${ }^{66}$ Zob. Z. Bereszyński, Opole polskie..., s. 174-176. 


\section{Bibliografia}

\section{Źródła archiwalne}

Archiwum Państwowe w Opolu

Komitet Wojewódzki Polskiej Zjednoczonej Partii Robotniczej w Opolu, sygn. 45/2579/0

Urząd Miejski w Opolu, sygn. 45/1501/0.

Komitet Zakładowy PZPR przy Zakładach Naprawczych Taboru Kolejowego w Opolu, sygn. $45 / 23490 / 0$.

\section{Prasa}

„Opolanin - 20 lat minęło, „Nowa Trybuna Opolska” z 17 października 2003 r..

Rosna mury największego budynku w Opolu. Mister naszego miasta?, „Trybuna Opolska” z 13 kwietnia $1972 \mathrm{r}$.

\section{Opracowania}

Bałtowski M., Gospodarka socjalistyczna w Polsce, Warszawa 2009.

Bereszyński Z., Instytut Śląski w Opolu w czasach rewolucji solidarnościowej (w świetle dokumentów sprawy obiektowej krypt. „Silesia”), cz. I, „Indeks. Pismo Uniwersytetu Opolskiego” 2007, nr 9-10.

Bereszyński Z., Opole polskie (1945-2010), [w:] Opole. Dzieje i tradycja, red. B. Linek, K. Tarka, U. Zajączkowska, Opole 2011.

Bereszyński Z., Pod znakiem "dynamicznego rozwoju”. Strategia gospodarcza PZPR po Grudniu '70 i jej realizacja na przykładzie województwa opolskiego - od optymistycznych prognoz i deklaracji po pierwsze oznaki kryzysu, „Studia Śląskie” 2016, t. 78.

Gediga B., Badania i dzieje wczesnośredniowiecznego grodu na Ostrówku w Opolu, [w:] Opole. Gród, miasto, stolica regionu. Materiaty z sesji popularnonaukowej zorganizowanej w Opolu 28 maja 1993 r., Opole 2002.

Hamada A., Opolski Biaty Dom, „Indeks. Pismo Uniwersytetu Opolskiego” 2005, nr 3-4.

Kołodko G., Polska w świecie inflacji, Warszawa 1987.

Krajewski M., Historia gospodarcza Polski do 1989 roku. Zarys problematyki, Włocławek 2000.

Kroszel J., Ludność, [w:] Opole. Monografia miasta, red. W. Dziewulski i F. Hawranek, Opole 1975.

Lis M., Historia PIN - Instytutu Śląskiego w Opolu, Państwowy Instytut Naukowy - Instytut Śląski w Opolu, https://instytutslaski.pl/historia-instytutu-slaskiego/ (dostęp: 28 października 2020 r.).

Matuszczyk E., Z przeszłości placu Kopernika, „Almanach miejski. Opolanin” 2001.

Nicieja S.S., Alma Mater Opoliensis. Ludzie - fakty - wydarzenia. Księga jubileuszowa w 50. rocznice Wyższej Szkoty Pedagogicznej w Opolu i 10. rocznice powstania Uniwersytetu Opolskiego, Opole 2004.

Roszkowski W., Najnowsza historia Polski 1945-1980, Warszawa 2003.

Sasanka P., Czerwiec 1976. Geneza - przebieg - konsekwencje, Warszawa 2017.

Sowa A.L., Historia polityczna Polski 1944-1991, Kraków 2011.

Sroka M., I sekretarze Komitetu Wojewódzkiego Polskiej Zjednoczonej Partii Robotniczej w Opolu w latach 1950-1990, „Studia Śląskie”, t. 78, Opole 2016.

Turwid K., Owacje i frustracje. Opolskie budowanie 1945-2005, Opole 2006. 


\title{
Zbigniew Bereszyński \\ Strategia dynamicznego rozwoju i jej realizacja na przykładzie Opola w latach 1971-1980
}

\begin{abstract}
Streszczenie
W 1971 r. władze Polskiej Rzeczypospolitej Ludowej wdrożyły nową strategię gospodarczą, określaną jako strategia dynamicznego rozwoju. Strategia ta, przewidująca szybki rozwój potencjału przemysłowego kraju w połączeniu z poprawą materialnych warunków życia społeczeństwa, zaowocowała również społeczno-gospodarczym rozwojem Opola. Miasto rozrosło się w sensie przestrzennym i demograficznym. Wzbogaciło się o nowe mieszkania i miejsca pracy. Rozwój miasta był jednak wybitnie nierównomierny. W latach 1971-1980 i później zmarnowano ogromną ilość środków finansowych i materialnych na przedsięwzięcia, których nigdy w pełni nie sfinalizowano bądź doprowadzono do końca z dużym opóźnieniem. Niektóre decyzje w sprawie nowych inwestycji okazały się z czasem źle pomyślane. Inwestycje z lat 19711980, oprócz oczywistych korzyści dla miasta, zrodziły również szereg poważnych problemów społecznych. Dziedzictwo to w niejednym przypadku nadal jeszcze bardzo ciąży miastu i jego mieszkańcom.
\end{abstract}

Słowa kluczowe: Opole, gospodarka, strategia dynamicznego rozwoju, inwestycje, rozwój

\section{Zbigniew Bereszyński}

\section{The strategy of dynamic growth - social and economic growth in Opole in the years 1971-1980}

\begin{abstract}
In 1971 the authorities of the Polish People's Republic implemented a new economic strategy, referred to as the strategy of dynamic growth. The strategy, which assumed rapid industrial growth in combination with an improvement in the living conditions for the general society, resulted in social and economic development, also in the city of Opole. The city grew both in territorial and demographic terms, gaining more housing resources and more jobs. However, this growth was extremely uneven. In the years 1971-1980 and later, enormous amounts of money and materials were wasted on ventures which were significantly delayed or never completed. In hindsight, some decisions regarding new investments turned out to be misguided. On the one hand, investments from the years 1971-1980 benefited the city, but on the other, they caused a number of serious social problems. In many cases, this legacy is still an enormous burden for the city and its residents.
\end{abstract}

Keywords: Opole, economy, strategy of dynamic growth, investments, development. 